GEOLOGICAL SURVEY OF DENMARK AND GREENLAND BULLETIN 5 • 2004

The Jurassic of North-East Greenland

Edited by

Lars Stemmerik and Svend Stouge 


\title{
Geological Survey of Denmark and Greenland Bulletin 5
}

\section{Keywords}

Ammonites, Boreal, dinoflagellate cysts, Jurassic, North-East Greenland, palaeogeography, rifting, siliciclastic sediments, stratigraphy

\section{Cover}

Eastwards-dipping Middle-Upper Jurassic sandstones (yellow) and interbedded marine mudstones (dark) at the base of the coastal cliffs along the south-east coast of Traill $\varnothing$. The Jurassic succession is described by Vosgerau et al. (this volume). It is disconformably overlain by poorly exposed Cretaceous siltstones with numerous volcanic intrusions that form ledges towards the top of the $c$. $1050 \mathrm{~m}$ high cliff. Photo: Lars Stemmerik.

\section{Frontispiece: facing page}

Middle Jurassic and Lower Cretaceous sandstones exposed on the western slopes of Steensby Bjerg, Hold with Hope, viewed towards the north-east with Finsch Øer in the centre and Clavering $\varnothing$ in the far distance. On Hold with Hope, a more than $500 \mathrm{~m}$ thick sedimentary succession of Triassic-Cretaceous age is exposed in the north-facing coastal cliffs. The Jurassic succession, which was not recognised until field work in 1996, is preserved in the downfaulted hangingwall blocks of a series of rotated half-grabens formed during the main East Greenland rifting phase in the latest Jurassic to earliest Cretaceous. Lower Cretaceous sandstones, up to $170 \mathrm{~m}$ thick, unconformably overlie the rift succession. Photo: Michael Larsen.

Chief editor of this series: Peter R. Dawes

Scientific editors: Lars Stemmerik and Svend Stouge, in conjunction with Jon R. Ineson

Copy editors: Jon R. Ineson and Birgit Eriksen

Editorial secretary: Birgit Eriksen

Critical readers: D.J. Batten, G. Bloos, Walter K. Christiansen, Gregers Dam, Susanne Feist-Burkhardt, Jon Gjelberg, G.F.W. Herngreen, Jan Jansonius, Michael Larsen, J.B. Riding, D. Strogen, Finn Surlyk, A. Wierzbowski

Drawing work: Jette Halskov

Photographic work: Jacob Lautrup, Benny M. Schark

Lay-out and graphic production: Knud Gr@phic Consult, Odense, Denmark

Printers: Schultz Grafisk, Albertslund, Denmark

Manuscripts submitted: 31 January 2000 - 20 March 2001

Final versions approved: 22 January 2001 - 5 November 2002

Printed: 1 November 2004

ISBN 87-7871-135-5

\section{Geological Survey of Denmark and Greenland Bulletin}

The series Geological Survey of Denmark and Greenland Bulletin replaces Geology of Denmark Survey Bulletin and Geology of Greenland Survey Bulletin.

\section{Citation of the name of this series}

It is recommended that the name of this series is cited in full, viz. Geological Survey of Denmark and Greenland Bulletin. If abbreviation of this volume is necessary, the following form is suggested: Geol. Surv. Den. Green. Bull. 5, 112 pp.

\author{
Available from \\ Geological Survey of Denmark and Greenland \\ Øster Voldgade 10, DK-1350 Copenhagen K, Denmark \\ Phone: +45 381420 00, fax: +45 381420 50, e-mail: geus@geus.dk \\ or \\ Geografforlaget ApS \\ Rugårdsvej 55, DK-5000 Odense C, Denmark \\ Phone: +45634416 83, fax: +45634416 97, e-mail: go@geografforlaget.dk
}

\section{(C) Danmarks og Grønlands Geologiske Undersøgelse (GEUS), 2004}




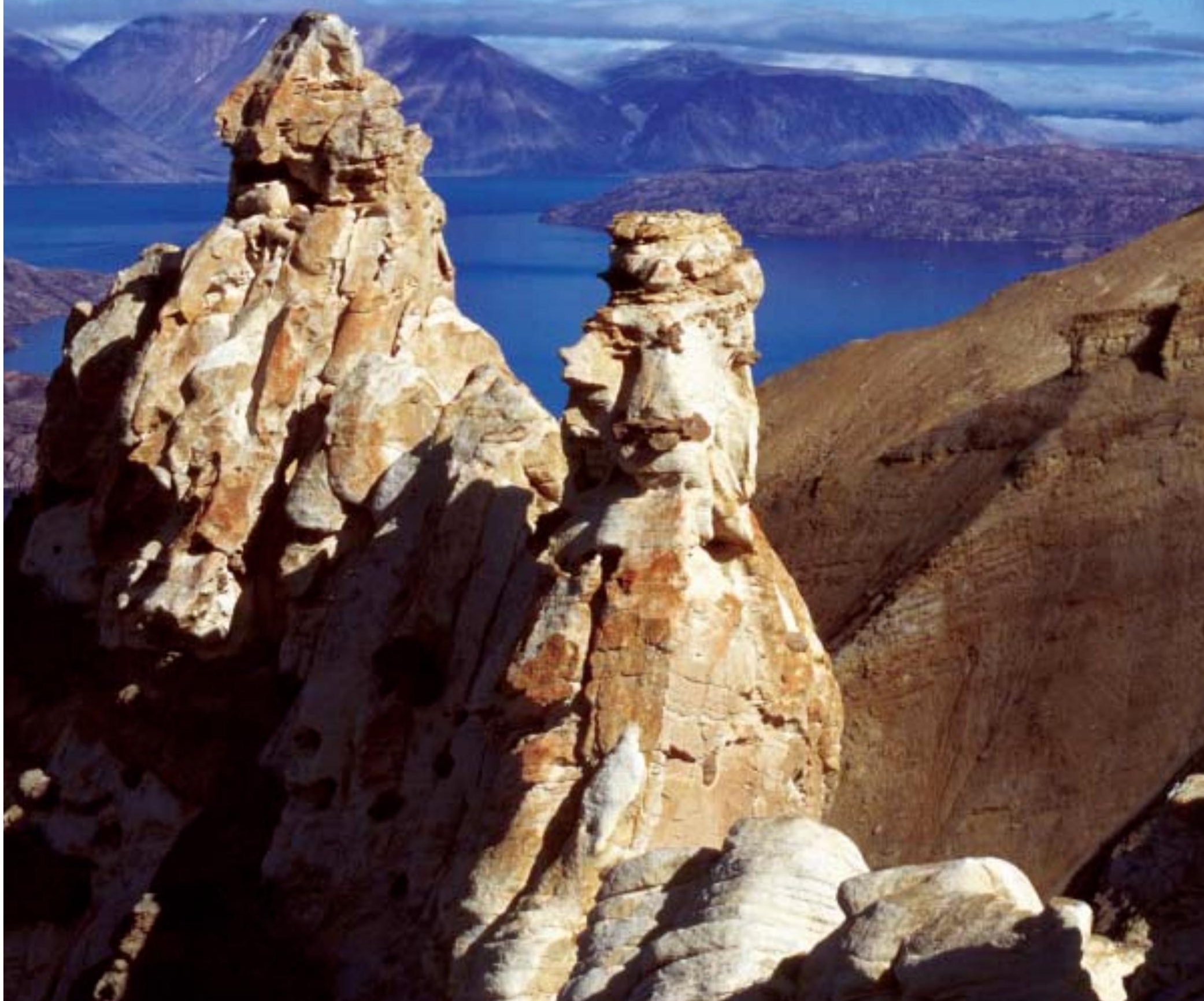





\section{Contents}

Preface

Jurassic syn-rift sedimentation on a seawards-tilted fault block, Traill $\varnothing$, North-East Greenland

Henrik Vosgerau, Peter Alsen, Ian D. Carr, Jens Therkelsen, Lars Stemmerik and Finn Surlyk . . . . . . . . . . . 9

The fluviatile Bristol Elv Formation, a new Middle Jurassic lithostratigraphic unit from Traill $\varnothing$, North-East Greenland

Jens Therkelsen and Finn Surlyk .

Maximum Middle Jurassic transgression in East Greenland: evidence from new ammonite finds, Bjørnedal, Traill $\varnothing$

Peter Alsen and Finn Surlyk. Appendix by John H. Callomon

A new Middle-Upper Jurassic succession on Hold with Hope, North-East Greenland

Henrik Vosgerau, Michael Larsen, Stefan Piasecki and Jens Therkelsen .

Jurassic dinoflagellate cyst stratigraphy of Hold with Hope, North-East Greenland

Stefan Piasecki, Michael Larsen, Jens Therkelsen and Henrik Vosgerau .

Jurassic dinoflagellate cysts from Hochstetter Forland, North-East Greenland

Stefan Piasecki and Lars Stemmerik . . . . . . . . . . . . . . . . . . . . . . . . . . . .

Jurassic dinoflagellate cyst stratigraphy of Store Koldewey, North-East Greenland

Stefan Piasecki, John H. Callomon and Lars Stemmerik . 


\section{Preface}

The Jurassic sedimentary succession in East and NorthEast Greenland reflects deposition during the early stages of rifting between Greenland and Norway. Jurassic sediments are exposed over a distance of more than $600 \mathrm{~km}$, from Jameson Land in the south to Store Koldewey in the north (Fig. 1), and form one of the best-known exposed ancient rift successions. The sediments have been intensely studied over the last 25 years and a synthesis of the Jurassic System in Greenland was recently given in Geological Survey of Denmark and Greenland Bulletin 1 (Surlyk 2003).

This collection of papers deals with stratigraphic and depositional aspects of the Middle-Upper Jurassic sediments from isolated and less well-known localities outside the main outcrop areas, and thus adds to the tremendous amount of new data generated from the classical Jurassic successions of Jameson Land and the Wollaston Forland area (Ineson \& Surlyk 2003). Most papers are based on fieldwork in 1996 and 1997, carried out within the framework of the project 'Resources of the sedimentary basins of North and East Greenland' supported by the Danish Research Councils (see Stemmerik et al. 1997). Papers dealing with the Jurassic at Store Koldewey and Hochstetter Forland are based on material collected during regional mapping in 1989 (Stemmerik \& Piasecki 1990).

During Middle-Late Jurassic times, rifting took place along major N-S-trending synthetic faults that delimited wide westwards-tilted fault blocks (Surlyk 1977, 2003). This resulted in the development of elongated marine embayments with major rivers entering from the north and dominantly axial sediment transport towards the south (Surlyk 1978, 2003; Engkilde \& Surlyk 2003). The Jurassic syn-rift succession on south-eastern Traill $\varnothing$ is an exception to this general pattern (Vosgerau et al. 2004a, this volume). Sedimentation took place on an eastwards-tilted fault block; the succession shows an eastwards proximal-distal decrease in sandstone-mudstone ratio, reflecting increasing water depths to the east. On the adjacent fault block to the west, a new lithostratigraphic unit, the Bristol Elv Formation, has been erected to describe a succession of fluvio-lacustrine sediments at the base of the Middle Jurassic rift succession (Therkelsen \& Surlyk 2004, this volume). The non-marine succession is overlain by shallow marine sandstones of the Pelion Formation (Upper Bajocian), succeeded in turn by $25-30 \mathrm{~m}$ of black silty mudstones of the Fossilbjerget Formation

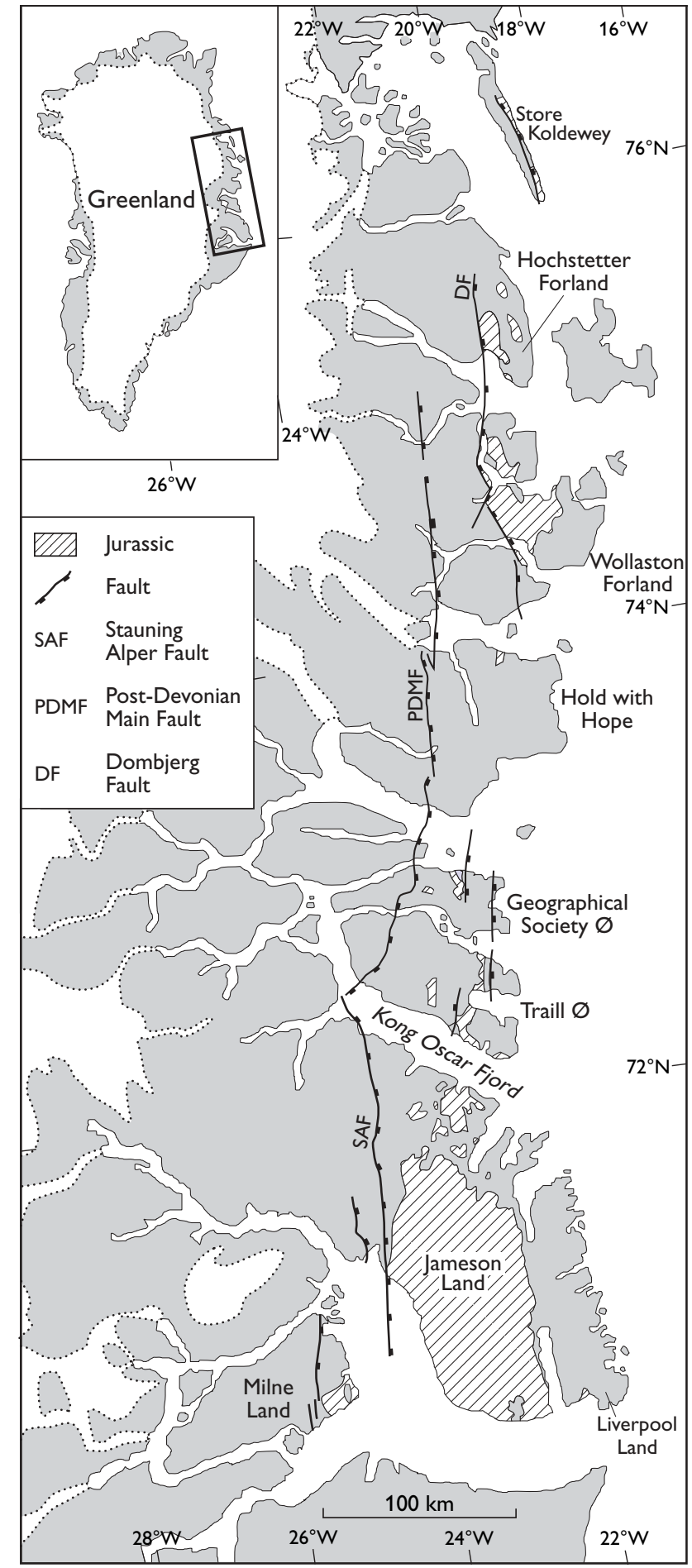

Fig. 1. Simplified geological map of East and North-East Greenland showing the distribution of Jurassic sediments. Modified from Surlyk (2003). 
(Alsen \& Surlyk 2004, this volume). The presence of the Fossilbjerget Formation on southern Traill $\varnothing$ indicates complete drowning of the sandy Pelion system during maximum Middle Jurassic transgression (Alsen \& Surlyk 2004, this volume).

A new Middle-Upper Jurassic succession was found in the hangingwalls of small fault blocks at Hold with Hope during fieldwork in 1996 (Stemmerik et al. 1997). The up to $360 \mathrm{~m}$ thick succession and its stratigraphy are described in detail by Vosgerau et al. (2004b, this volume) and Piasecki et al. (2004a, this volume). The succession resembles that seen at Wollaston Forland and Kuhn $\varnothing$. The Hold with Hope area was flooded during late Middle Jurassic time; Lower-Middle Callovian shallow marine sandstones of the Pelion Formation overlie Lower Triassic sediments (Vosgerau et al. 2004b, this volume). The overlying sandstones of the Payer Dal Formation are of Middle-Late Oxfordian age. The uppermost part of the succession belongs to the Bernbjerg Formation. The youngest sediments are of Late Oxfordian - Early Kimmeridgian age based on dinoflagellate cysts (Piasecki et al. 2004a, this volume). Dinoflagellate cysts have also been used to date the scattered outcrops of Middle-Upper Jurassic sediments at Hochstetter Forland and Store Koldewey further to the north (Piasecki \& Stemmerik 2004, this volume; Piasecki et al. 2004b, this volume). The dinoflagellate cyst assemblages of these northern outliers are readily correlated to assemblages described from the MiddleUpper Jurassic further to the south in East Greenland, and also show some resemblance to assemblages described from North Greenland (Piasecki et al. 2004b, this volume).

\section{Lars Stemmerik}

\section{References}

Alsen, P. \& Surlyk, F. 2004: Maximum Middle Jurassic transgression in East Greenland: evidence from new ammonite finds, Bjørnedal, Traill $\varnothing$. In: Stemmerik, L. \& Stouge, S. (eds): The Jurassic of North-East Greenland. Geological Survey of Denmark and Greenland Bulletin 5, 31-49 (this volume).

Engkilde, M. \& Surlyk, F. 2003: Shallow marine syn-rift sedimentation: Middle Jurassic Pelion Formation, Jameson Land, East Greenland. In: Ineson, J.R. \& Surlyk, F. (eds): The Jurassic of Denmark and Greenland. Geological Survey of Denmark and Greenland Bulletin 1, 813-863.
Ineson, J.R. \& Surlyk, F. (eds) 2003: The Jurassic of Denmark and Greenland. Geological Survey of Denmark and Greenland Bulletin 1, 948 pp.

Piasecki, S. \& Stemmerik, L. 2004: Jurassic dinoflagellate cysts from Hochstetter Forland, North-East Greenland. In: Stemmerik, L. \& Stouge, S. (eds): The Jurassic of North-East Greenland. Geological Survey of Denmark and Greenland Bulletin 5, 89-97 (this volume).

Piasecki, S., Larsen, M., Therkelsen, J. \& Vosgerau, H. 2004a: Jurassic dinoflagellate cyst stratigraphy of Hold with Hope, North-East Greenland. In: Stemmerik, L. \& Stouge, S. (eds): The Jurassic of North-East Greenland. Geological Survey of Denmark and Greenland Bulletin 5, 73-88 (this volume).

Piasecki, S., Callomon, J.H. \& Stemmerik, L. 2004b: Jurassic dinoflagellate cyst stratigraphy of Store Koldewey, North-East Greenland. In: Stemmerik, L. \& Stouge, S. (eds): The Jurassic of North-East Greenland. Geological Survey of Denmark and Greenland Bulletin 5, 99-112 (this volume).

Stemmerik, L. \& Piasecki, S. 1990: Post-Caledonian sediments in North-East Greenland between $76^{\circ}$ and $78^{\circ} 30^{\prime} \mathrm{N}$. Rapport Grønlands Geologiske Undersøgelse 148, 123-126.

Stemmerik, L., Clausen, O.R., Korstgård, J., Larsen, M., Piasecki, S., Seidler, L., Surlyk, F. \& Therkelsen, J. 1997: Petroleum geological investigations in East Greenland: project 'Resources of the sedimentary basins of North and East Greenland'. Geology of Greenland Survey Bulletin 176, 29-38.

Surlyk, F. 1977: Stratigraphy, tectonics and palaeogeography of the Jurassic sediments of the areas north of Kong Oscars Fjord, East Greenland. Bulletin Grønlands Geologiske Undersøgelse 123, 56 pp.

Surlyk, F. 1978: Jurassic basin evolution of East Greenland. Nature 274(5667), 130-133.

Surlyk, F. 2003: The Jurassic of East Greenland: a sedimentary record of thermal subsidence, onset and culmination of rifting. In: Ineson, J.R. \& Surlyk, F. (eds): The Jurassic of Denmark and Greenland. Geological Survey of Denmark and Greenland Bulletin 1, 659-722.

Therkelsen, J. \& Surlyk, F. 2004: The fluviatile Bristol Elv Formation, a new Middle Jurassic lithostratigraphic unit from Traill $\varnothing$, North-East Greenland. In: Stemmerik, L. \& Stouge, S. (eds): The Jurassic of North-East Greenland. Geological Survey of Denmark and Greenland Bulletin 5, 19-29 (this volume).

Vosgerau, H., Alsen, P., Carr, I.D., Therkelsen, J., Stemmerik, L. \& Surlyk, F. 2004a: Jurassic syn-rift sedimentation on a seawards-tilted fault block, Traill $\varnothing$, North-East Greenland. In: Stemmerik, L. \& Stouge, S. (eds): The Jurassic of North-East Greenland. Geological Survey of Denmark and Greenland Bulletin 5, 9-18 (this volume).

Vosgerau, H., Larsen, M., Piasecki, S. \& Therkelsen, J. 2004b: A new Middle-Upper Jurassic succession on Hold with Hope, North-East Greenland. In: Stemmerik, L. \& Stouge, S. (eds): The Jurassic of North-East Greenland. Geological Survey of Denmark and Greenland Bulletin 5, 51-71 (this volume). 